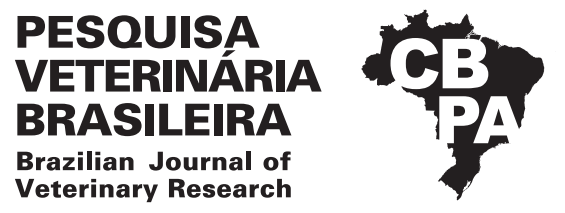

Pesq. Vet. Bras. 39(6):409-415, June 2019 DOI: 10.1590/1678-6160-PVB-6029

ISSN 0100-736X (Print)

ISSN 1678-5150 (Online)

\title{
Non-invasive ECG recording and QT interval correction assessment in anesthetized rats and mice ${ }^{1}$
}

\author{
Ana F.M. Botelho², Julliane V. Joviano-Santos ${ }^{3}$, Artur Santos-Miranda ${ }^{4}$, \\ José E.R. Menezes-Filho ${ }^{4}$, Benito Soto-Blanco², Jáder S. Cruz ${ }^{4}$, \\ Cristina Guatimosim ${ }^{3}$ and Marília M. Melo²*
}

\begin{abstract}
Botelho A.F.M., Joviano-Santos J.V., Santos-Miranda A., Menezes-Filho J.E.R., Soto-Blanco B., Cruz J.S., Guatimosim G. \& Melo M.M. 2019. Non-invasive ECG recording and QT interval correction assessment in anesthetized rats and mice. Pesquisa Veterinária Brasileira 39(6):409-415. Departamento de Clínica e Cirurgia Veterinária, Escola de Veterinária, Universidade Federal de Minas Gerais, Av. Antônio Carlos 6627, Belo Horizonte, MG 30123-970, Brazil. E-mail: mariliamm@ufmg.br

Rats and mice are the most common species used in experimental cardiac electrophysiology studies. Electrocardiogram (ECG) recording shows paramount importance for monitoring arrhythmias and cardiac function in several disease models, including QT syndrome. However, the lack of standardized reference values and QT correction formula for different animal species and lineages represent a challenge for ECG interpretation. The aim of this study is to provide an improved method for ECG recording, establishing reference range values and determine the QT formulas with higher correlation to heart rate (HR). A total of 10 Wistar rats, 10 Swiss mice, $10 \mathrm{C} 57 \mathrm{BL} / 6$ mice and $10 \mathrm{FVB} / \mathrm{NJ}$ mice were used in the study. Animals were submitted to anesthesia with isoflurane and ECG recording was performed using a six-channel non-invasive electrocardiograph. QT was corrected using the following formulas: Bazzett, Fridericia, Mitchell, Hodges, Van der Water and Framingham. Normal range values for ECG parameters were established in all animals studied. Pearsons' correlation defined Hodges formula as the most suitable for QT correction. This study demonstrated an improved method of ECG recording with reference values for Swiss, FVB/NJ, C57BL/6 mice, and Wistar rats. Hodges' formula was the most effective formula for QT correction in rodents, whereas Bazett's and Friderica formulas were ineffective for such animals. The present work contributes to arrhythmias investigation in experimental cardiology and may reduce misinterpretations in rodents' ECG.
\end{abstract}

INDEX TERMS: Non-invasive ECG, QT, interval correction, rats, mice, anesthesia, Hodges, Bazzet, Mitchell, QT correction formula.

RESUMO.- [Eletrocardiograma não invasivo e avaliação da correção do intervalo QT em roedores anestesiados.] Ratos e camundongos são as espécies mais comumente utilizadas em

\footnotetext{
${ }^{1}$ Received on July 21, 2018.

Accepted for publication on March 27, 2019.

${ }^{2}$ Departamento de Clínica Veterinária e Cirurgia, Faculdade de Veterinária, Universidade Federal de Minas Gerais (UFMG), Av. Antônio Carlos 6627, Belo Horizonte, MG 31270-901, Brazil. *Corresponding author: mariliamm@ufmg.br

${ }^{3}$ Departamento de Morfologia, Instituto de Ciências Biológicas, Universidade Federal de Minas Gerais (UFMG), Av. Antônio Carlos 6627, Belo Horizonte, MG 31270-901.

${ }^{4}$ Departamento de Bioquímica e Imunologia, Instituto de Ciências Biológicas, Universidade Federal de Minas Gerais (UFMG), Av. Antônio Carlos 6627, Belo Horizonte, MG 31270-901.
}

estudos experimentais de eletrofisiologia cardíaca. 0 registro do eletrocardiograma (ECG) é de suma importância para o monitoramento de arritmias e função cardíaca em vários modelos de patologias. No entanto, a falta de valores de referência padronizados e a fórmula de correção do QT para diferentes espécies e linhagens animais representam um desafio para a interpretação do ECG. 0 objetivo deste estudo é fornecer um método melhorado para o registro de ECG, estabelecendo valores de referência e determinar as fórmulas QT com maior correlação com a freqüência cardíaca (FC). Um total de 10 ratos Wistar, 10 camundongos Swiss, 10 camundongos C57BL/6 e 10 camundongos FVB/NJ foram utilizados no estudo. Os animais foram submetidos à anestesia com isoflurano e o registro de ECG foi realizado com eletrocardiógrafo 
não invasivo de seis canais. O QT foi corrigido usando as seguintes fórmulas: Bazzett, Fridericia, Mitchell, Hodges, Van der Water e Framingham. Os valores da normalidade para os parâmetros do ECG foram estabelecidos em todos os animais estudados. A correlação de Pearson definiu a fórmula de Hodges como a mais adequada para a correção do QT. Este estudo demonstra um método melhorado de registro de ECG com valores de referência para camundongos Swiss, FVB/NJ, C57BL/6 e Wistar. A fórmula de Hodges foi a mais eficaz para correção de QT em roedores, enquanto as fórmulas de Bazett e Friderica apresentaram valores mais baixos de correlação. 0 presente trabalho contribui para a investigação de arritmias em cardiologia experimental e pode reduzir interpretações erradas no ECG de roedores.

TERMOS DE INDEXAÇÃO: Eletrocardiograma não invasivo, correção do intervalo QT, roedores, anestesia, Hodges, Bazzet, Mitchell, fórmula de correção do QT.

\section{INTRODUCTION}

Rats and mice are the most common species used in experimental cardiac physiology and electrophysiology studies (Zaragoza et al. 2011, Nerbonne 2014, Surikow et al. 2017). Several disease models including myocardial infarction (Heywood et al. 2017), diabetic cardiomyopathy (Bugger \& Abel 2009), hypertrophic and dilated cardiomyopathy (Xu et al. 2014, Yu et al. 2014), Chagas' disease (Roman-Campos et al. 2013) and QT syndrome (Drum et al. 2014) are well established in such animals. Some number techniques can be used to monitor and characterize cardiovascular pathologies, specially the electrocardiogram (ECG) exam.

The ECG is a valuable tool for cardiac electrical function evaluation and paramount importance for the diagnostic and monitoring of arrhythmias and conduction disturbances. Changes in the ECG waves and intervals, as well as waveform alterations and arrhythmias are particularly important in pharmacological and toxicological investigations of drugs, especially aiming to determine the safety of its therapeutic use (Ruppert et al. 2016).

ECG is routinely used in human medicine and experimental research. Since its description by Einthoven (1895) several adjustments and improvements have been made to increase its' precision and to reduce interferences (Wilson et al. 1934, Holter \& Generelli 1949). Several methodologies have been described in the search for the most adequate technique, including telemetry, invasive ECG, non-invasive ECG and Holter monitoring. Both conscious and anesthetized models were also studied over the years with its' positive and negative points to be considered in each model (Ho et al. 2011, Kumar et al. 2017). However, in the last few years computerized non-invasive ECG introduced new forms of analyzing its' parameters, with greater accuracy and storage capacity than conventional technique (Camacho et al. 2010, Pinto et al. 2010).

Enhanced data collection allows researchers to further investigate waves and intervals alterations and provide insights into discrete changes. One of the most important intervals evaluated in mice and rat models is the QT. It is known that QT interval represents depolarization and repolarization of ventricular action potential, and several diseases and drugs are implicated in its' prolongation. However, QT interval is dependent of the heart rate and different formulas throughout the years have tried to correct such variations, but no consensus was achieved (Bazett 1920, Fridericia 1920, Hodges et al. 1983, Van der Water et al. 1989, Sagie et al. 1992, Mitchell et al. 1998, Vandenberk et al. 2016).

Understanding the biological basis of QT correction is important to improve interpretation of ventricular abnormalities associated with progressive and fatal arrhythmias (Harada et al. 2010, Niemeijer et al. 2014). In fact, QT prolongation and its shortening are present in several pathologic disturbances, including intoxication with cardioactive drugs, myocardial infarction and QT syndrome (Yap \& Camm 2003, Nachimuthu etal. 2012). It is important to highlight that the correction is widely recommended in clinical practice and experimental studies, but the best correction formula for computerized electrocardiographic studies with anesthetized animals is undetermined.

Currently, the best animal model for QT interval studies uses guinea pigs (Cavia porcellus) due to the functional expression of channels responsible for potassium current known as Ikr (Rees \& Curtis 1993). However, the majority of studies still uses rats and mice, because of the easy access to such species and previously established diseases models (Chu et al. 2001, Andrag \& Curtis 2013). ECG interpretation in rodents is a challenge, due to the difficulty in determining the isoeletric point of the tracings. Some authors suggest evaluation of QT interval at $90 \%$ of repolarization (Rees \& Curtis 1993). On the other hand, this value is only accurately measured in isolated hearts in Langendorff system, which makes the experimental conduction and ECG interpretation even more challenging (Stables \& Curtis 2009, Andrag \& Curtis 2013).

Considering the animal models research importance, the increasing use of computerized electrocardiography and the QT formula discrepancies, the aim of this study is to provide an improved method for ECG recording, to establish normal range values and to determine the QT formulas with higher correlation to heart rate (HR).

\section{MATERIALS AND METHODS}

Ethics statement. The experiment was conducted at Veterinary School, UFMG, Brazil, in compliance with the Ethics Principles in Animal Experimentation, approved by the Ethics Committee on Animal Experimentation (CEUA-UFMG) (Protocols \#74/2017 and 25/2015). Health and welfare were evaluated through clinical examination by a trained veterinary.

Experimental design. All animal used in this study were healthy adults (4-8 months), provided by the Central Bioterium of "Universidade Federal de Minas Gerais" (UFMG), Brazil. Ten Wistar rats (Rattus novergicus albinus), 10 Swiss mice (Mus musculus), 10 C57BL/6 mice (M. musculus) and $10 \mathrm{FVB} / \mathrm{NJ}$ mice (M. musculus) were selected. They were kept in the Laboratory of Animal Experimentation of Veterinary School (UFMG) in Belo Horizonte, Minas Gerais, Brazil. Groups of 4-6 animals were kept in plastic cages $(36 \times 26 \times 15 \mathrm{~cm})$, under controlled environment, with 12 hours light/dark cycle and room temperature at $23^{\circ} \mathrm{C}$. They had free access to water and food.

ECG recording. A six-channel non-invasive electrocardiograph (ECG-PC version $2.07^{\circledR}$, Tecnologia Eletrônica Brasileira (TEB), Belo Horizonte/MG, Brazil) was used. The animals were induced with $2.5 \%$ isoflurane and maintained with $1.5 \%$ (VetCase - Incotec, Serra/ES, Brazil). Rodents were placed in a dorsal recumbence position on a wooden table covered with plastic material; electrocardiographic gel was applied, and four alligator clip electrodes were attached 
to the skin in the forelimbs and hindlimbs (Botelho et al. 2016). All procedures were performed in a quiet room to minimize stress.

ECG trace analysis. All ECGs were performed and analyzed by the same veterinary according to standard methods. Tracings were recorded in six leads of the frontal plan, with $50 \mathrm{~mm} / \mathrm{s}$ of velocity and sensitivity of $1 \mathrm{~cm}=2 \mathrm{mV}(2 \mathrm{~N})$. In each tracing three segments, containing five beats (lead II) were selected for quality (clean baseline with no artifacts) and mean values for heart rate (HR), and amplitude and length of P-QRS-T deflections were determined. The parameters evaluated were heart rate (HR) and cardiac rhythm, duration of the $P$ wave (Pms), QRS complex (QRS), PR and QT intervals, and amplitude of $\mathrm{P}$ waves $(\mathrm{PmV}), \mathrm{R}$ waves and $\mathrm{T}$ waves. Morphology patterns and rhythm were evaluated in every lead, and P-QRS-T measurements were conducted in lead II. QT corrected values were obtained from the following equations (Table 1 ).

Statistical analysis. All measurements are expressed as mean \pm standard deviation (SD). The influence of the different QT formulas was compared by the Pearson's test (variables normally distributed). In all the analyses differences were considered to significant when $\mathrm{P}<0.05$.

\section{RESULTS}

ECG tracings of the distinct species/lineages are shown in (Fig.1) and similar wave morphology and deflections amongst the derivations is observed. Predominantly in all animals DI, DII, DIII and aVF are positive whilst avR and aVL are negative. Rats presented the most challenging evaluation of the ST segment and all lineages/species presented discrete $Q$ wave. Mean, standard deviation, minimum and maximum values of the electrocardiographic parameters (HR, Pms, PmV, PR, WRS, R, T, QT) of Swiss mice, C57BL/6 mice, FVB/NJ mice and Wistar rats are described in Table 2 to 5 .

Pearson's test evaluated the correlation amongst QT correction formulas, QT, HR and RR presented in Table 6. In all evaluated animals, Van der Water's formula had the perfect correlation when compared with uncorrected QT. However, the strongest correlation with RR and HR was obtained by Hodge's formula, presenting all r values higher than 0.9 (Fig.2).

Table 1. QT correction formulas used in this study and their respective references

\begin{tabular}{|c|c|}
\hline QT formula & Reference \\
\hline $\mathrm{QTcB}=\mathrm{QT}^{*}(\mathrm{RR})^{1 / 2}$ & Bazett 1920 \\
\hline $\mathrm{QTcF}=\mathrm{QT}^{*}(\mathrm{RR})^{1 / 3}$ & Fridericia 1920 \\
\hline $\mathrm{QTcV}=\mathrm{QT}+0.087(1-\mathrm{RR})$ & Van der Water et al. 1989 \\
\hline $\left.\mathrm{QtcFr}=\mathrm{QT}+0.154^{*}(1-\mathrm{RR})\right]$ & Sagie et al. 1992 \\
\hline $\mathrm{QTcM}=\mathrm{QT} /$ square root of $(\mathrm{RR} / 100)$ & Mitchell et al. 1998 \\
\hline $\mathrm{QTcH}=\mathrm{QT}+0.00175 \times(\mathrm{HR}-60)$ & Hodges et al. 1983 \\
\hline
\end{tabular}

Table 2. Mean, standard deviation, minimum and maximum values of the electrocardiographic parameters of Swiss mice. Tracings were recorded in six derivations of the frontal plan, with $50 \mathrm{~mm} / \mathrm{s}$ of velocity and sensitivity of $1 \mathrm{~cm}=2 \mathrm{mV}(2 \mathrm{~N})$ in healthy adult anesthetized mice (Mus musculus) using a computerized ECG

\begin{tabular}{lccc}
\hline \multicolumn{1}{c}{ Parameters } & Mean \pm SD & Min & Max \\
\hline HR (bpm) & $434.90 \pm 68.43$ & 321 & 502 \\
P (ms) & $29.29 \pm 2.62$ & 25 & 33 \\
P (mV) & $0.028 \pm 0.005$ & 0.02 & 0.03 \\
PR (ms) & $36.20 \pm 3.22$ & 32 & 40 \\
QRS (ms) & $41.66 \pm 5.02$ & 33 & 53 \\
R (mV) & $0.22 \pm 0.05$ & 0.19 & 0.27 \\
T (mV) & $0.028 \pm 0.011$ & 0.020 & 0.05 \\
QT (ms) & $83.16 \pm 8.37$ & 63 & 92
\end{tabular}

$\mathrm{HR}=$ Heart rate, $\mathrm{Pms}=$ duration of the $\mathrm{P}$ wave, $\mathrm{PmV}=$ amplitude of $\mathrm{P}$ wave, $\mathrm{PRms}=$ duration of the PR segment, $\mathrm{QRSms}=$ duration of the QRS complex, $\mathrm{RmV}=$ amplitude of $\mathrm{R}$ wave, $\mathrm{TmV}=$ amplitude of $\mathrm{T}$ wave, QTms = duration of QT interval.
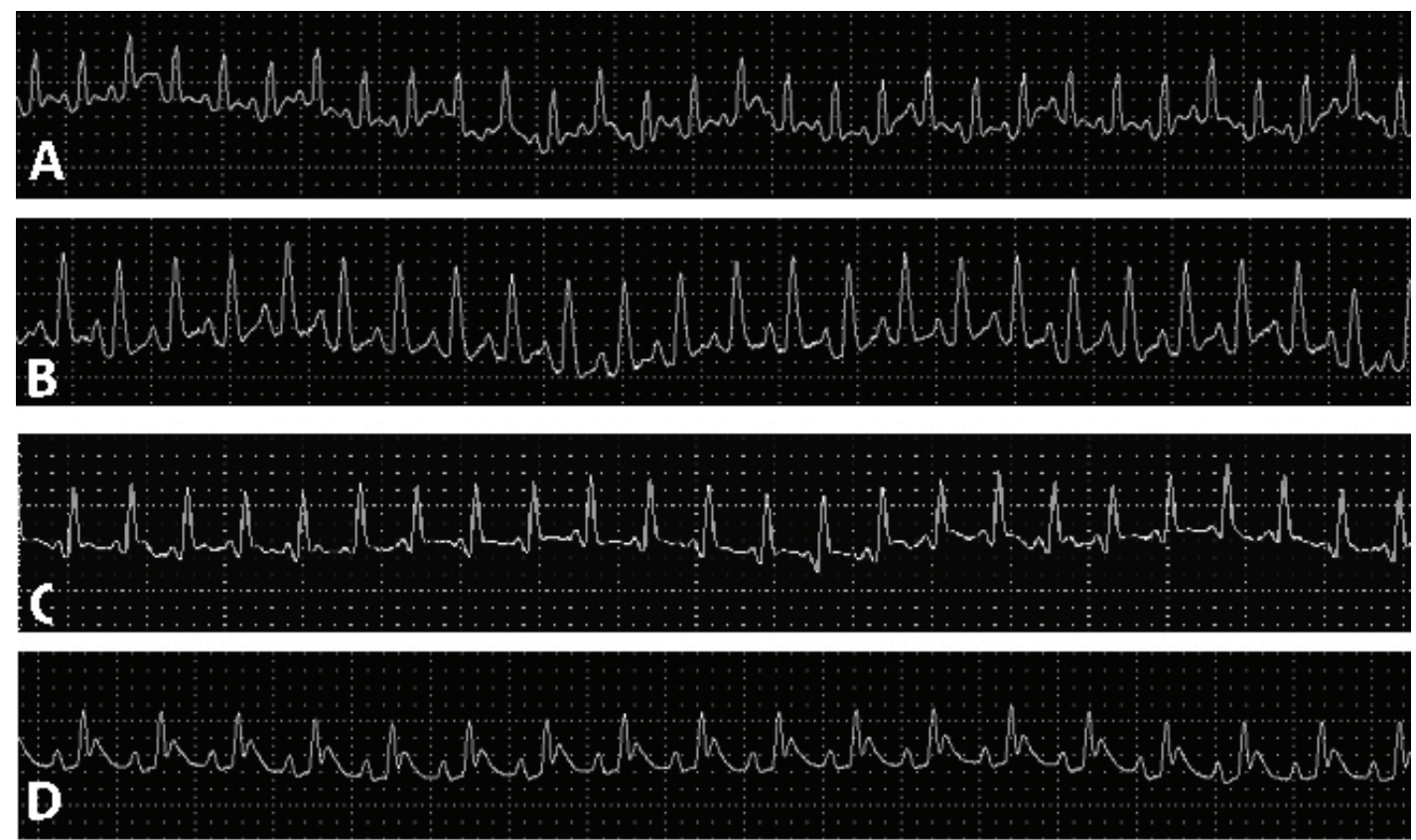

Fig.1. Computerized electrocardiographic tracings of healthy anesthetized (A) Swiss, (B) C57BL/6, (C) FVB/NJ mice and (D) Wistar rat. Recordings of the second deviation of the frontal plane (DII), with velocity of $50 \mathrm{~mm} / \mathrm{s}$ and amplitude $2 \mathrm{~N}$. Red tracings determine the QT interval. 
Table 3. Mean, standard deviation, minimum and maximum values of the electrocardiographic parameters of C57BL/6 mice. Tracings were recorded in six derivations of the frontal plan, with $50 \mathrm{~mm} / \mathrm{s}$ of velocity and sensitivity of $1 \mathrm{~cm}=2 \mathrm{mV}$

(2N) in healthy adult anesthetized mice (Mus musculus) using a computerized ECG

\begin{tabular}{lccc}
\hline \multicolumn{1}{c}{ Parameters } & Mean \pm SD & Min & Max \\
\hline HR $(\mathrm{bpm})$ & $432.75 \pm 81.79$ & 281 & 510.4 \\
P (ms) & $31.23 \pm 3.67$ & 25.2 & 37 \\
P (mV) & $0.034 \pm 0.008$ & 0.02 & 0.055 \\
PR $(\mathrm{ms})$ & $46.13 \pm 5.77$ & 38.2 & 38.00 \\
QRS $(\mathrm{ms})$ & $43.39 \pm 4.58$ & 38.2 & 51.80 \\
R (mV) & $0.15 \pm 0.04$ & 0.09 & 0.227 \\
T (mV) & $0.033 \pm 0.014$ & 0.02 & 0.594 \\
QT $(\mathrm{ms})$ & $88.53 \pm 8.37$ & 75 & 123
\end{tabular}

$\mathrm{HR}=$ Heart rate, $\mathrm{Pms}=$ duration of the $\mathrm{P}$ wave, $\mathrm{PmV}=$ amplitude of $\mathrm{P}$ wave, $\mathrm{PRms}=$ duration of the PR segment, $\mathrm{QRSms}=$ duration of the $\mathrm{QRS}$ complex, $\mathrm{RmV}=$ amplitude of $\mathrm{R}$ wave, $\mathrm{TmV}=$ amplitude of $\mathrm{T}$ wave, QTms = duration of QT interval.

Table 4. Mean, standard deviation, minimum and maximum values of the electrocardiographic parameters of $\mathrm{FVB} / \mathrm{NJ}$ mice. Tracings were recorded in six derivations of the frontal plan, with $50 \mathrm{~mm} / \mathrm{s}$ of velocity and sensitivity of $1 \mathrm{~cm}=2 \mathrm{mV}$

(2N) in healthy adult anesthetized mice (Mus musculus) using a computerized ECG

\begin{tabular}{lccc}
\hline \multicolumn{1}{c}{ Parameters } & Mean \pm SD & Min & Max \\
\hline HR (bpm) & $478.58 \pm 69.06$ & 374 & 516.3 \\
P (ms) & $31.12 \pm 3.89$ & 27 & 38 \\
P (mV) & $0.038 \pm 0.008$ & 0.02 & 0.054 \\
PR (ms) & $32.09 \pm 3.51$ & 29 & 37 \\
QRS $(\mathrm{ms})$ & $40.55 \pm 3.30$ & 34.5 & 46 \\
R (mV) & $0.20 \pm 0.08$ & 0.15 & 0.363 \\
T (mV) & $0.03 \pm 0.006$ & 0.02 & 0.041 \\
QT $(\mathrm{ms})$ & $82.26 \pm 6.87$ & 71 & 95
\end{tabular}

$\mathrm{HR}=$ Heart rate, $\mathrm{Pms}=$ duration of the $\mathrm{P}$ wave, $\mathrm{PmV}=$ amplitude of $\mathrm{P}$ wave, $\mathrm{PRms}=$ duration of the PR segment, $\mathrm{QRSms}=$ duration of the $\mathrm{QRS}$ complex, $\mathrm{RmV}=$ amplitude of $\mathrm{R}$ wave, $\mathrm{TmV}=$ amplitude of $\mathrm{T}$ wave, QTms = duration of QT interval.

Table 5. Mean, standard deviation, minimum and maximum values of the electrocardiographic parameters of Wistar rats. Tracings were recorded in six derivations of the frontal plan, with $50 \mathrm{~mm} / \mathrm{s}$ of velocity and sensitivity of $1 \mathrm{~cm}=2 \mathrm{mV}(2 \mathrm{~N})$ in healthy adult anesthetized rats (Rattus novergicus) using a computerized ECG

\begin{tabular}{llcc}
\hline \multicolumn{1}{c}{ Parameters } & Mean \pm SD & Min & Max \\
\hline HR $(\mathrm{bpm})$ & $326 \pm 57.45$ & 189 & 378 \\
P (ms) & $34.40 \pm 5.01$ & 25 & 43 \\
P (mV) & $0.050 \pm 0.015$ & 0.03 & 0.082 \\
PR (ms) & $54.50 \pm 10.14$ & 48 & 75 \\
QRS $(\mathrm{ms})$ & $34.10 \pm 4.58$ & 27 & 42 \\
R (mV) & $0.182 \pm 0.064$ & 0.13 & 0.293 \\
T (mV) & $0.046 \pm 0.02$ & 0.03 & 0.086 \\
QT $(\mathrm{ms})$ & $75.60 \pm 11.89$ & 62 & 98
\end{tabular}

$\mathrm{HR}=$ Heart rate, $\mathrm{Pms}=$ duration of the $\mathrm{P}$ wave, $\mathrm{PmV}=$ amplitude of $\mathrm{P}$ wave, $\mathrm{PRms}=$ duration of the PR segment, $\mathrm{QRSms}=$ duration of the QRS complex, $\mathrm{RmV}=$ amplitude of $\mathrm{R}$ wave, $\mathrm{TmV}=$ amplitude of $\mathrm{T}$ wave, $\mathrm{QTm}$ = duration of QT interval.
Table 6. Pearson's correlation values between QT correction formulas of adult healthy Swiss mice, C57BL/6 mice, FVB/NJ mice and Wistar rats. The following formulas were used:

Bazett, Fridericia, Van der Water, Framingham, Hodges

and Mitchell. Recordings were made in six derivations of the frontal plan, with $50 \mathrm{~mm} / \mathrm{s}$ of velocity and sensitivity of $1 \mathrm{~cm}=2 \mathrm{mV}(2 \mathrm{~N})$ using a computerized ECG

\begin{tabular}{|c|c|c|c|}
\hline Swiss & $\mathrm{RR}$ & HR & QT \\
\hline QTcB & -0.536 & 0.559 & 0.717 \\
\hline QtcFri & -0.341 & 0.365 & 0.852 \\
\hline QTcV & 0.2 & -0.175 & 1 \\
\hline QTcH & -0.988 & 0.998 & -0.107 \\
\hline QtcFra & -0.256 & 0.277 & 0.896 \\
\hline QTcM & -0.461 & 0.458 & 0.682 \\
\hline C57BL/6 & $\mathrm{RR}$ & HR & QT \\
\hline QTcB & 0.05 & -0.035 & 0.689 \\
\hline QtcFri & 0.397 & -0.380 & 0.9 \\
\hline QTcV & 0.756 & -0.735 & 1 \\
\hline QTcH & -0.977 & -0.998 & -0.687 \\
\hline QtcFra & 0.502 & -0.482 & 0.946 \\
\hline QTcM & 0.033 & -0.017 & 0.676 \\
\hline $\mathrm{FVB} / \mathrm{NJ}$ & $\mathrm{RR}$ & HR & QT \\
\hline QTcB & -0.329 & 0.267 & 0.613 \\
\hline QtcFri & -0.012 & -0.053 & 0.833 \\
\hline QTcV & 0.541 & -0.594 & 1 \\
\hline QTcH & -0.966 & 0.999 & -0.553 \\
\hline QtcFra & 0.191 & -0.251 & 0.902 \\
\hline QTcM & -0.344 & 0.286 & 0.573 \\
\hline Wistar & $\mathrm{RR}$ & HR & QT \\
\hline QTcB & -0.222 & 0.334 & 0.754 \\
\hline QtcFri & -0.002 & 0.120 & 0.880 \\
\hline QTcV & 0.473 & -0.359 & 1 \\
\hline QTcH & -0.954 & 0.993 & -0.243 \\
\hline QtcFra & -0.019 & 0.125 & 0.713 \\
\hline QTcM & 0.226 & 0.339 & 0.750 \\
\hline
\end{tabular}

$\overline{\mathrm{QTcB}}=\mathrm{QT}^{*}(\mathrm{RR}) 1 / 2$ (Bazett 1920), QTcFRI $=\mathrm{QT}^{*}(\mathrm{RR}) 1 / 3$ (Fridericia 1920), QTcV = QT + 0.087(1- RR) (Van der Water et al. 1989), $\mathrm{QTcFRA}=\mathrm{QT}+0.154 *(1-\mathrm{RR})]$ (Sagie et al. 1992) and QTcM = QT $/$ square root of (RR/100) (Mitchell et al. 1998).

\section{DISCUSSION}

ECG is routinely used in both medicine and experimental research and although it defined as a simple technique, its interpretation may often be challenging. The lack of standardization for ECG parameters is an important gap for research comparisons. Different experimental designs, such as type of electrodes and anesthesia, age and size of the animals partake in its misinterpretation (Konopelski \& Ufnal 2016).

The present work aims to contribute to such studies using the most common species and lineages evaluated in cardiovascular research. The use of a non-invasive six-channel ECG (Botelho et al. 2016) and isoflurane anesthesia is a well-known technique that provides harmless, safe and low-cost recording with high repeatability (Murakami et al. 2014). Ten animals were evaluated considering the similarity amongst rodents as previous works evaluating ECG variations showed such number is sufficient to establish correlations of its parameters (Roussel et al. 2016). 

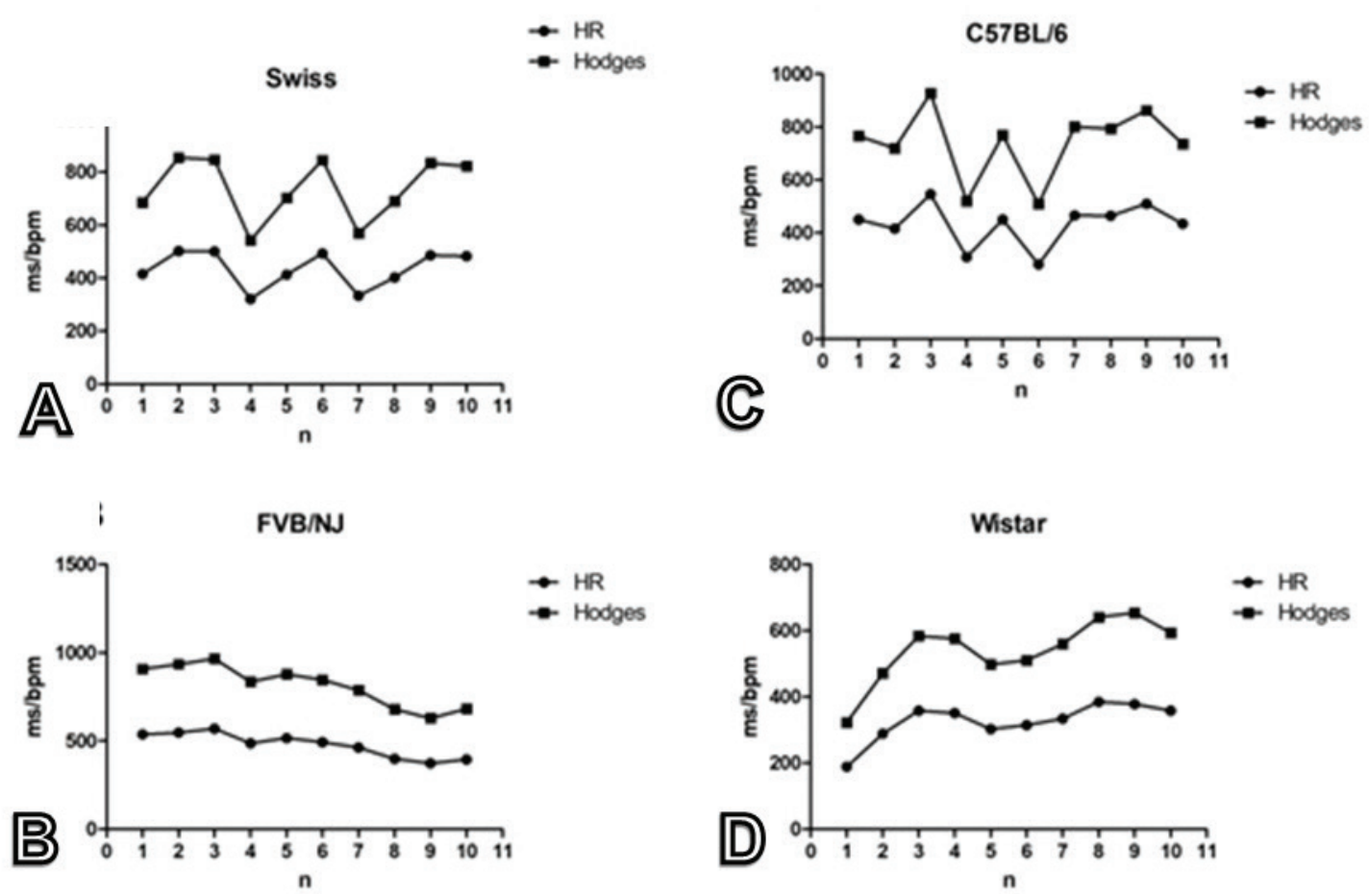

Fig.2. Pearson's correlation between Hodge's QT correction formula and hear rate (HR) studied in healthy adult anesthetized (A) Swiss,

(B) C57BL/6, (C) FVB/NJ mice and (D) Wistar rats.

Mice mean HR of the lineages study was about $450 \mathrm{bpm}$, similar to previous studies (Shintaku etal. 2014). It is noteworthy that HR is affected by the type of anesthesia used in all rodent species. For example, ether anesthesia of Wistar rats defines HR between 290-378 bpm (Fraser et al. 1967), under urethane anesthesia from 357-452bpm (Buschmann et al. 1980), while ketamine and xylazine from 242-336bpm (Miranda et al. 2007). The present work describes $326 \pm 57.45 \mathrm{bpm}$ in accordance to values previously found ( $320 \pm 6 \mathrm{bpm}$ ) (Murakami et al. 2014).

PR interval is also affected by anesthesia and was reported in Wistar rats to be 39 to $78 \mathrm{~ms}$ and of $35.7 \pm 0.9 \mathrm{~ms}$ in mice (Shintaku et al. 2014). The present study revealed similar mean values of 34.4 for rats and 35.7 for mice. Previous work has described important electrophysiological differences amongst animals (Boukens et al. 2014), especially regarding the expression of ionic channels that may influence the atrioventricular conduction and therefore PR interval. Although anatomy and weight of the mice are similar, the singularities in electrophysiological parameters amongst lineages may be responsible for the differences in PR value.

Concerning QT correction, the different correlations amongst formulae reveals the importance in establishing the most adequate for animal models and methodology. Previous studies used formulas more suitable for human parameters, may have generated misguidedly values (Costa et al. 2008) as each formula is more suitable for a specific HR range. Our findings reveal that Hodge's formula has the best correlation to HR/RR and therefore should be used for this model. The lowest correlations were found for Bazett and Fridericia as they are more appropriate to HR lower than those found in rats and mice. This finding is particularly important for hypokalemia evaluation, ischemia, myocardial infarction, channelopathies, drug toxicity, and overall pathologies that disturb cardiomyocyte repolarization. As QT prolongation is one of the predictors of ventricular arrhythmias, its thorough evaluation may provide insights into rodent ECG alterations and better correlate human disease to animal models. A recent study using anesthetized mice showed that QT has little correlation to HR (Roussel et al. 2016); however, there is no consensus on whether anesthetized models require adjustment of QT to HR (Hayes et al. 1994, Kmecova \& Klimas 2010), as the majority of rat studies uses one of several formulas to calculate QTc (Hamdy \& Brocks 2009). Nonetheless, the present work using different anesthetized rodents showed there is a moderate to high correlation between corrected QT and RR/HR.

\section{CONCLUSIONS}

Considering the proposed model for ECG evaluation, our study describes the references intervals for Swiss, FVB/NJ, C57BL/6 mice and Wistar rats. It also suggests that Hodge's formula is the most suitable QT correction formula and that Bazett's and Fridericia formulas used for such animals should be questioned.

The present work contributes to electrocardiographic investigation in experimental cardiology and may reduce misinterpretations in rodents' ECG.

Acknowledgement: This study was supported by the "Fundação de Amparo de Pesquisa de Minas Gerais" (FAPEMIG), Brazil: grant \#APQ03578-16 and by “Conselho Nacional de Desenvolvimento Científico e Tecnológico" (CNPq): grant \#424241/2016.

Conflict of interest statement: The authors have no competing interests. 


\section{REFERENCES}

Andrag E. \& Curtis M.J. 2013. Feasibility of targeting ischemia-related ventricular arrhythmias by mimicry of endogenous protection by endocannabinoids. Brit. J. Pharmacol. 169(8):1840-1848. <http://dx.doi. org $/ 10.1111 /$ bph.12252>

Bazett H.C. 1920. An analysis of the time-relations of electrocardiograms. Heart 7:353-370.

Botelho A.F.M., Oliveira M.S., Soto-Blanco B. \& Melo M.M. 2016. Computerized electrocardiography in healthy conscious guinea pigs (Cavia porcellus) Pesq. Vet. Bras. 36(12):1203-1208. <http://dx.doi.org/10.1590/s0100736x2016001200011>

Boukens B.J., Rivaud M.R., Rentschler S. \& Coronel R. 2014. Misinterpretation of the mouse ECG: musing the waves of Mus musculus. J. Physiol. 592(21):46134626. <http://dx.doi.org/10.1113/jphysiol.2014.279380><PMid:25260630>

Bugger H. \& Abel E.D. 2009. Rodent models of diabetic cardiomyopathy. Dis. Model. Mech. 2(9/10):454-466. <http://dx.doi.org/10.1242/dmm.001941> $<$ PMid:19726805>

Buschmann G., Schumacher W., Budden R. \& Kuhl U.G. 1980. Evaluation of the effect of dopamine and other catecholamines on the electrocardiogram and blood pressure of rats by means of on-line biosignal processing. J. Cardio. Pharmacol. 2(6):777-795. <http://dx.doi.org/10.1097/00005344198011000-00008> <PMid:6160328>

Camacho A.A., Paulino Jr D., Pascon J.P.E. \& Teixeira A.A. 2010. Comparison between conventional and computerized electrocardiography in cats. Arq. Bras. Med. Vet. Zootec. 62(3):765-769. <http://dx.doi.org/10.1590/ S0102-09352010000300038>

Chu V., Otero J.M., Lopez O., Morgan J.P., Amende I. \& Hampton T.G. 2001 Method for non-invasively recording electrocardiograms in conscious mice. BMC Physiol. 1(1):6. <http://dx.doi.org/10.1186/1472-6793-1-6> $<$ PMid:11476671>

Costa E.C., Gonçalves A.A., Areas M.A. \& Morgabel R.G. 2008. Effects of metformin on QT and QTc interval dispersion of diabetic rats. Arq. Bras. Cardiol 90(4):254-260. <http://dx.doi.org/10.1590/S0066-782X2008000400004> <PMid:18516382>

Drum B.M., Dixon R.E., Yuan C., Cheng E.P. \& Santana L.F. 2014. Cellular mechanisms of ventricular arrhythmias in a mouse model of Timothy syndrome (long QT syndrome). J. Mol. Cell Cardiol. 66:63-71. <http:// dx.doi.org/10.1016/j.yjmcc.2013.10.021 > <PMid:24215710>

Einthoven W. 1895. Ueber die Form des menschlichen Electrocardiogramms. Pflugers Arch. Gesamte Physiol. Menschen Tiere 60(3/4):101-123. <http:// dx.doi.org/10.1007/BF01662582>

Fraser R.S., Harley C. \& Wiley T. 1967. Electrocardiogram in the normal rat. J. Appl. Physiol. 23(3):401-402. <http://dx.doi.org/10.1152/ jappl.1967.23.3.401><PMid:6047963>

Fridericia L.S. 1920. Die Systolendauer im Elektrokardiogramm bei normalen Menschen und bei Herzkranken. [The duration of systole in the electrocardiogram of normal subjects and of patients with heart disease.]. Acta Med. Scand. 53(1):469-486. <http://dx.doi.org/10.1111/j.0954-6820.1920.tb18266.x>

Hamdy D.A. \& Brocks D.R. 2009. Experimental hyperlipidemia causes an increase in the electrocardiographic changes associated with amiodarone. J. Cardio. Pharmacol. 53(1):1-8. <http://dx.doi.org/10.1097/FJC.0b013e31819359d1> <PMid:19129743>

Harada T., Ishizaki F., Hamada M., Horie N., Nitta Y., Nitta K., Katsuoka H. \& Nakamura S. 2010. Circadian rhythm of heart rate variability and autonomic cardiovascular regulation in Parkinson's disease. Auton. Neurosci. 158(1/2):133-140. <http://dx.doi.org/10.1016/j.autneu.2010.07.016>

Hayes E., Pugsley M.K., Penz W.P., Adaikan G. \& Walker J.A. 1994. Relationship between QT and RR interval in rats, guinea pigs, rabbits and primates. J. Pharmacol. Toxicol. Methods 32(4):201-207.<http://dx.doi.org/10.1016/10568719(94)90088-4> <PMid:7881134>

Heywood S.E., Richart A.L., Henstridge D.C., Alt K., Kiriazis H., Zammit C., Carey A.L., Kammoun H.L., Delbridge L.M., Reddy M., Chen Y.C., Du X.J., Hagemeyer C.E., Febbraio M.A., Siebel A.L. \& Kingwell B.A. 2017. Highdensity lipoprotein delivered after myocardial infarction increases cardiac glucose uptake and function in mice. Sci. Transl. Med. 9(411):eaam6084. <http://dx.doi.org/10.1126/scitranslmed.aam6084><PMid:29021167>

Ho H.T., Stevens S.C., Terentyeva R., Carnes C.A., Terentyev D. \& Györke S. 2011. Arrhythmogenic adverse effects of cardiac glycosides are mediated by redox modification of ryanodine receptors. J. Physiol. 589(Pt 19):4697-4708. <http://dx.doi.org/10.1113/jphysiol.2011.210005> <PMid:21807619>

Hodges M., Salerno D. \& Erlien D. 1983. Bazett's QT correction reviewed. Evidence that a linear QT correction for heart is better. J. Am. Coll. Cardiol. $1: 694$.

Holter N.J. \& Generelli J.A. 1949. Remote recording of physiologic data by radio. Rocky Mt. Med. J. 46(9):747-751. <PMid:18137532>

Kmecova J. \& Klimas J. 2010. Heart rate correction of the QT duration in rats. Eur. J. Pharmacol. 641(2/3):187-192.<http://dx.doi.org/10.1016/j. ejphar.2010.05.038 ><PMid:20553920 >

Konopelski P. \& Ufnal M. 2016. Electrocardiography in rats: a comparison to human. Physiol. Res. 65(5):717-725. <PMid:27429108>

Kumar P., Srivastava P., Gupta A. \& Bajpai M. 2017. Non-invasive recording of electrocardiogram in conscious rat: a new device. Indian J. Pharmacol. 49(1):116-118. <PMid:28458434>

Miranda A., Costa-e-Sousa R.H., Werneck-de-Castro J.P., Mattos E.C., Olivares E.L., Ribeiro V.P., Silva M.G., Goldenberg R.C. \& Campos-de-Carvalho A.C. 2007. Time course of echocardiographic and electrocardiographic parameters in myocardial infarct in rats. Anais Acad. Bras. Ciênc. 79(4):639-648. <http:// dx.doi.org/10.1590/S0001-37652007000400006> <PMid:18066433>

Mitchell G.F., Jeron A. \& Koren G. 1998. Measurement of heart rate and QT interval in the conscious mice. Am. J. Physiol. 274(3):H747-H751. <PMid:9530184>

Murakami M., Niwa H., Kushikata T., Watanabe H., Hirota K., Ono K. \& Ohba T. 2014. Inhalation anesthesia is preferable for recording rat cardiac function using an electrocardiogram. Biol. Pharm. Bull. 37(5):834-839. <http:// dx.doi.org/10.1248/bpb.b14-00012><PMid:24790005>

Nachimuthu S., Assar M.D. \& Schussler J.M. 2012. Drug-induced QT interval prolongation mechanisms and clinical management. Therap. Adv. Drug Safety 3(5):241-253. <http://dx.doi.org/10.1177/2042098612454283> <PMid:25083239>

Nerbonne J.M. 2014. Mouse models of arrhythmogenic cardiovascular disease: challenges and opportunities. Current Opinion Pharmacol. 15:107-114. <http://dx.doi.org/10.1016/j.coph.2014.02.003> <PMid:24632325>

Niemeijer M.N., Van den Berg M.E., Eijgelsheim M., Van Herpen G., Stricker B.H., Kors J.A. \& Rijnbeek P.R. 2014. Short-term QT variability markers for the prediction of ventricular arrhythmias and sudden cardiac death: a systematic review. Heart 100(23):1831-1836. <http://dx.doi.org/10.1136/ heartjnl-2014-305671><PMid:25092875>

Pinto M.C.L., Borboleta L.R., Melo M.B., Labarrère C.R. \& Melo M.M. 2010. Tityus fasciolatus envenomation induced cardio-respiratory alterations in rats. Toxicon 55(6):1132-1137. <http://dx.doi.org/10.1016/j. toxicon.2010.01.002><PMid:20060851>

Rees S.A. \& Curtis M.J. 1993. Selective IK blockade as an antiarrhythmic mechanism: effects of UK66, 914 on ischemia and reperfusion arrhythmias in rat and rabbit heart. Brit. J. Pharmacol. 108(1):139-145. <http://dx.doi. org/10.1111/j.1476-5381.1993.tb13453.x><PMid:8428204>

Roman-Campos D., Sales-Júnior P., Duarte H.L., Gomes E.R., Guatimosim S., Ropert C., Gazzinelli R.T. \& Cruz J.S. 2013. Cardiomyocyte dysfunction during the chronic phase of Chagas disease. Mem. Inst. Oswaldo Cruz 108(2):243-245. <http://dx.doi.org/10.1590/0074-0276108022013019> <PMid:23579807>

Roussel J., Champeroux P., Roy J., Richard S., Fauconnier J., Le Guennec J.Y. \& Thireau J. 2016. The complex QT/RR relationship in mice. Sci. Rep. 6(1):25388. <http://dx.doi.org/10.1038/srep25388><PMid:27138175>

Ruppert S., Vormberge T., Igl B.W. \& Hoffmann M. 2016. ECG telemetry in conscious guinea pigs. J. Pharmacol. Toxicol. Methods 81:88-98. <http:// dx.doi.org/10.1016/j.vascn.2016.04.013><PMid:27118261> 
Sagie A., Larson M.G., Goldberg R.J., Bengtson J.R. \& Levy D. 1992. An improved method for adjusting the QT interval for heart rate (the Framingham Heart Study). Am. J. Cardiol. 70(7):797-801.<http://dx.doi.org/10.1016/00029149(92)90562-D> <PMid:1519533>

Shintaku T., Ohba T., Niwa H., Kushikata T., Hirota K., Ono K., Matsuzaki Y., Imaizumi T., Kuwasako K., Sawamura D. \& Murakami M. 2014. Effects of propofol on electrocardiogram measures in mice. J. Pharmacol. Sci. 126(4):351-358. <http://dx.doi.org/10.1254/jphs.14181FP><PMid:25409900>

Stables C.L. \& Curtis M.J. 2009. Development and characterization of a mouse in vitro model of ischemia-induced ventricular fibrillation. Cardiovasc. Res. 83(2):397-404. <http://dx.doi.org/10.1093/cvr/cvp068><PMid:19228704>

Surikow S.Y., Nguyen T.H., Stafford I., Chapman M., Singh K., Licari G., Raman B.H., Frenneaux M.P. \& Horowitz J.D. 2017. Development of therapeutic strategies for Takotsubo syndrome: insights from a rat model. Circulation 136:A18970.

Van der Water A., Verheyen J., Xhonneux R. \& Reneman R.S. 1989. An improved method to correct the QT interval of the electrocardiogram for changes in heart rate. J. Pharmacol. Toxicol. Methods 22(3):207-217. <PMid:2586115>

Vandenberk B., Vandael E., Robyns T., Vandenberghe J., Garweg C., Foulon V., Ector J. \& Willems R. 2016. Which QT correction formulae to use for QT monitoring? J. Am. Heart Assoc. 5(6):e003264. <http://dx.doi.org/10.1161/ JAHA.116.003264><PMid:27317349>
Wilson N.F., Johnston F.E., Macleod A.G. \& Barker P.S. 1934. Electrocardiograms that represent the potential variations of a single electrode. Am. J. Heart 9(4):447-458. <http://dx.doi.org/10.1016/S0002-8703(34)90093-4>

Xu X., Roe N.D., Weiser-Evans M.C. \& Ren J. 2014. Inhibition of mammalian target of rapamycin with rapamycin reverses hypertrophic cardiomyopathy in mice with cardiomyocyte-specific knockout of PTEN. Hypertension 63(4):729-739.<http://dx.doi.org/10.1161/HYPERTENSIONAHA.113.02526> <PMid:24446058>

Yap Y.G. \& Camm A.J. 2003. Drug induced prolongation and torsades de pointes. Heart 89(11):1363-1372. <http://dx.doi.org/10.1136/heart.89.11.1363> <PMid:14594906>

Yu Q., Li Q., Na R., Li X., Liu B., Meng L., Liutong H., Fang W., Zhu N. \& Zheng X. 2014. Impact of repeated intravenous bone marrow mesenchymal stem cells infusion on myocardial collagen network remodeling in a rat model of doxorubicin-induced dilated cardiomyopathy. Mol. Cell. Biochem. 387(1/2):279-285. <http://dx.doi.org/10.1007/s11010-013-1894-1> <PMid:24257807>

Zaragoza C., Gomez-Guerrero C., Martin-Ventura J.L., Blanco-Colio L., Lavin B., Mallavia B., Tarin C., Mas S., Ortiz A. \& Egido J. 2011. Animal models of cardiovascular diseases. J. Biomed. Biotechnol. 2011:497841. <http://dx.doi. org/10.1155/2011/497841><PMid:21403831> 